\title{
Disease Recurrence Indicator
}

National Cancer Institute

\section{Source}

National Cancer Institute. Disease Recurrence Indicator. NCI Thesaurus. Code C123621.

An indication as to whether disease recurrence occurred. 